\title{
Selecting and analysing climate change adaptation measures at six research sites across Europe
}

\author{
Henk-Jan van Alphen ${ }^{1}$, Clemens Strehl ${ }^{2}$, Fabian Vollmer ${ }^{2}$, Eduard Interwies $^{3}$, Anasha Petersen ${ }^{3}$, Stefan Görlitz $^{3}$, \\ Luca Locatelli ${ }^{4}$, Montse Martinez Puentes ${ }^{4}$, Maria Guerrero Hidalga ${ }^{5}$, Elias Giannakis ${ }^{6}$, Teun Spek $^{7}$, Marc Scheibel $^{8}$, \\ Erle Kristvik $^{9}$, Fernanda Rocha ${ }^{10}$, and Emmy Bergsma ${ }^{1}$ \\ ${ }^{1}$ KWR Water Research Institute, Nieuwegein, 3433 PE, the Netherlands \\ ${ }^{2}$ IWW Water Centre, 45476 Mülheim an der Ruhr, Germany \\ ${ }^{3}$ InterSus - Sustainability Services, 10405 Berlin, Germany \\ ${ }^{4}$ Aquatec (Suez Spain), 08038 Barcelona, Spain \\ ${ }^{5}$ CETAQUA Water Technology Centre, 08940 Barcelona, Spain \\ ${ }^{6}$ The Cyprus Institute, Energy Environment and Water Research Center, Nicosia, 2121, Cyprus \\ ${ }^{7}$ Province of Gelderland, Arnhem, 6811CG, the Netherlands \\ ${ }^{8}$ Wupperverband, 42289 Wuppertal, Germany \\ ${ }^{9}$ Norwegian University of Science and Technology, 7491 Trondheim, Norway \\ ${ }^{10}$ Laboratório Nacional de Engenharia Civil, 1700-066 Lisbon, Portugal
}

Correspondence: Henk-Jan van Alphen (henk-jan.van.alphen@kwrwater.nl)

Received: 29 May 2020 - Discussion started: 26 June 2020

Revised: 13 May 2021 - Accepted: 18 May 2021 - Published: 13 July 2021

\begin{abstract}
As Europe is faced with increasing droughts and extreme precipitation, countries are taking measures to adapt to these changes. It is challenging, however, to navigate through the wide range of possible measures, taking into account the efficacy, economic impact and social justice aspects of these measures, as well as the governance requirements for implementing them. This article presents the approach of selecting and analysing adaptation measures to increasing extreme weather events caused by ongoing climate change that was developed and applied in the $\mathrm{H} 2020$ project BINGO (Bringing Innovation to Ongoing Water Management). The purpose of this project is (a) to develop an integrated participatory approach for selecting and evaluating adaptation measures, (b) to apply and evaluate the approach across six case-study river basins across Europe, and (c) to support decision-making towards adaptation capturing the diversity, the different circumstances and challenges river basins face across Europe. It combines three analyses: governance, socio-economic and social justice The governance analysis focuses on the requirements associated with the measures and the extent to which these requirements are met at the research sites. The socio-economic impact focuses on the ef-
\end{abstract}

ficacy of the measures in reducing the risks and the broad range of tools available to compare the measures on their societal impact. Finally, a tentative social justice analysis focuses on the distributive impacts of the adaptation measures. In the summary of results, we give an overview of the outcome of the different analyses. In the conclusion, we briefly assess the main pros and cons of the different analyses that were conducted. The main conclusion is that although the research sites were very different in both the challenges and the institutional context, the approach presented here yielded decision-relevant outcomes.

\section{Introduction}

Along the process of adapting to climate change, finding and defining appropriate adaptation measures is a complex task. Moreover, it is the key activity to increase the resilience to future climate-change-induced risks (Dogulu and Kentel, 2015). In addition, good practice in selecting adaptation measures is a fundamental task in adjusting water infrastructure to climate change, which is globally needed (Wilby, 
2019). Part of this good practice is to analyse the impact of potential adaptation measures, not only in terms of hazard risk reduction, but also in terms of socio-economic effects, social justice or governance needs for implementation. For example, Zhou et al. (2012) combine climate modelling and an economic cost-benefit assessment in analysing climate adaptation measures for pluvial flooding in urban areas. Harrison et al. (2013) combine climate change scenarios with socio-economic scenarios in a digital platform to allow stakeholders to explore adaptation options within the context of varying futures. European research projects such as ECONADAPT and BASE have also focused on the economics of climate adaptation to support adaptation planning (Watkiss et al., 2015; Garotte et al., 2016; Meyer et al., 2015).

Another part of this good practice is to involve stakeholders in selecting and analysing these adaptation measures. Involving local stakeholders in these analyses, not just through consultation, but through co-production, enhances their relevance, usability, legitimacy and credibility (Palutikof et al., 2019). For example, Bhave et al. (2014) combine top-down climate modelling with bottom-up (involving stakeholders) prioritisation of adaptation measures but do not analyse socio-economic effect of measures or governance requirements for implementation. Andersson-Sköld et al. (2015) use focus group interviews with stakeholders to gauge the perceptions of adaptation measures, as part of a broader integrated framework to analyse the impact of climate adaptation measures. On the other hand, Singh et al. (2020) develop and apply a broad framework to assess the feasibility of adaptation measures, including political, economic and social indicators, but not specific to local conditions and not as part of a participatory framework. This study contributes to the literature by integrating three different analyses (governance, socio-economic and social justice) in a participatory framework, where most other studies capture only one or two of the above-mentioned dimensions (Verkerk et al., 2017; Bojovic et al., 2018; O’Sullivan et al., 2020).

This article presents the approach of selecting and analysing adaptation measures to increasing extreme weather events caused by ongoing climate change that was developed and applied in the H2020 project BINGO (Bringing Innovation to Ongoing Water Management). The purpose of this project is (a) to develop an integrated participatory approach for selecting and evaluating adaptation measures, (b) to apply and evaluate the approach across six case-study river basins across Europe, and (c) to support decision-making towards adaptation capturing the diversity, different circumstances and challenges river basins face across Europe. The project was conducted by over 20 project partners at six research sites in Europe: (1) the city of Badalona (Spain), which faces the risk of flash floods and combined sewer overflows (CSOs) due to increased precipitation; (2) the city of Bergen (Norway), also facing the risk of floods and CSOs due to increased precipitation; (3) Veluwe (Netherlands), a Natura 2000 site where long-term drought may affect the ground- water system; (4) the Troodos mountains (Cyprus), where decreasing precipitation causes water shortages for farmers and communities; (5) the Wupper River basin, which is divided into two sub-cases, one about flood risk due extreme weather events and one about decreasing water levels in the main water reservoir due to decreasing precipitation; and (6) the Sorraia Valley (Portugal) where farmers are confronted with water shortages due to decreasing precipitation.

The BINGO project followed a comprehensive approach from decadal predictions of weather events, to hydrological analysis of the impact of the weather events on water systems, to risk analysis and risk treatment. The work presented in this article focuses on the treatment of risks following extreme precipitation or drought. Risk treatment in project BINGO was organised as a collaborative process between scientists and local stakeholders, through communities of practice (CoPs) (Freitas et al., 2018). These CoPs consisted of representatives of local and regional governments, organisations involved in climate adaptation, and research partners. CoPs provide a social context in which researchers and stakeholders can engage in formal and informal interactions and co-analyse and co-produce the contextual knowledge that is necessary for climate change adaptation (Iyalomhe et al., 2013). The CoPs in the BINGO project were locally created and externally supported by the scientific project partners, which is found to be a necessary condition for a sustainable CoP (Vincent et al. 2018)

Based on the risks that were identified and analysed in the risk analysis, the CoPs selected and analysed adaptation measures, with the goal of informing decision makers about the expected efforts and gains from the implementation of these measures. The approach applied in the BINGO project is in line with steps formulated in the Adaptation Support Tool developed as part of the Climate-ADAPT initiative of the European Union (https://climate-adapt.eea.europa.eu/ knowledge/tools/adaptation-support-tool, last access: 8 July 2021). More resources from the BINGO project can be found on the project website (http://www.projectbingo.eu, last access: 8 July 2021).

The next sections describe the process of selecting and analysing promising adaptation measures in the order as conducted within the BINGO project for all cases: (1) collecting and selecting adaptation measures, (2) governance analysis of selected adaptation measures, (3) analysis of socioeconomic implications and (4) social justice analysis. These steps are illustrated with examples from the case study in the city of Badalona as well as from other sites in brief. A summary of the results of the analysis is provided, comparing different types of measures. Finally, conclusions are drawn on the application of the different methods. 


\section{Collecting and selecting adaptation measures}

Two approaches were applied to collect potential adaptation measures suitable to the climate change risks identified at the six research sites, namely a desk study of previous adaptation research and consultation of stakeholders involved in the local CoPs. For the desk study, the primary sources for adaptation measures were two previous EU research projects CarpathCC (http://www.carpathcc.eu/, last access: 8 July 2021) and PREPARED (https://cordis.europa. eu/project/id/244232, last access: 8 July 2021). From both projects databases were available with adaptation measures, including a brief analysis of their potential impact and risk reduction potential. From these databases the BINGO research partners selected measures that were (a) potentially relevant for the hazards the research sites are facing and (b) relevant for the main characteristics of the research site (e.g. urban area, agricultural area, natural area). At the same time, in each of the six research sites the first $\mathrm{CoP}$ meeting was organised. In this meeting, local stakeholders discussed and identified potential future climate hazards for their research site and identified measures that were either already planned or considered suitable.

These measures were collected as part of workshop reports (van Alphen et al., 2017a) and compiled, together with the measures from the desk research that were selected by the research sites. In total, 91 measures were collected. In many cases, research sites reported similar measures with slightly different wording, or very specific measures could be placed in a broader category. Through this reduction, 44 measures were compiled in a portfolio of adaptation measures (van Alphen et al., 2017b). The portfolio of adaptation measures is now available as an online tool (http://beta.tools.watershare. eu/bingo/\$/, last access: 8 July 2021). In the portfolio, different types of measures are distinguished: informational measures (e.g. raising awareness for behavioural change), financial measures (e.g. insurance and subsidies), regulatory measures (e.g. standards and legal bans) and infrastructural measures (e.g. flood control infrastructure). The complete set of measures can be filtered by type of risk, sector or adaptation objective. Since the portfolio was first created to support the work in BINGO, the broad risk categories reflected the risks first identified in the six case studies: (1) decrease in water quantity due to decreased precipitation, (2) decrease in water quality due to decreased precipitation, (3) floods due to increased precipitation and (4) decrease in water quality due to increased precipitation. The sectors reflected the sectors represented in the case studies: (1) agriculture, (2) flood management, (3) public water supply, (4) urban drainage, (5) water governance and (6) water resource management. This design was chosen so project partners and future users can easily find measures suited to their own circumstances. For each measure an analysis of the governance needs for implementation was given, based on the three-layer framework presented below. This analysis was done by research partners and was not based on specific conditions at the research sites, but on desk research.

After compiling this broad portfolio, a more specific assessment of potential risks at the research site was made and discussed with stakeholders. Local stakeholders could make a selection of adaptation measures from the long list provided by the project team and the measures that were developed locally. This first selection of measures was accompanied by a discussion on the following governance aspects related to the measures: (1) responsibility for implementation, (2) participation/division of roles, (3) availability of necessary resources and (4) potential challenges. During the CoP meetings at the six research sites, these aspects were discussed for the different measures, and a selection was made either through scoring or through voting. The measures were selected for the purpose of further analysis. For instance, in the case of Cyprus, measures were first scored on relevance and feasibility and then voted on by the stakeholders. In some cases, stakeholders decided to analyse measures that were not part of the portfolio but came up in the stakeholder process after the portfolio was already compiled. Table 1 shows the selection of measures for each research site.

\section{Governance analysis of selected adaptation measures}

\subsection{Three-layer framework}

The three-layer framework for water governance, a tool for assessing water governance practices (Havekes et al., 2016), was used to analyse the governance needs of the adaptation measures. The framework builds on the work done by the Organisation for Economic Co-operation and Development (OECD 2011) on governance gaps in water governance and elaborates on these gaps with building blocks for good water governance identified by the Dutch Water Governance Centre. The framework distinguishes between three layers of governance: the content layer, the institutional layer and the relational layer. First, the content layer looks into the substance of adaptation measures. Measures are characterised by the risk that they address (such as from floods, CSOs or droughts) and the type of intervention (informational, financial, regulatory, infrastructural). Also, the content layer addresses the type of knowledge and expertise needed to implement the measure (technical knowledge, administrative knowledge, knowledge about interest and preferences). Second, the institutional layer deals with the broad range of organisational requirements for the implementation of adaptation measures. This entails (1) the involvement of the necessary actors and a clear division of roles and responsibilities between them; (2) the administrative resources to implement the measure, such as staff, accounting and monitoring capacities, regulatory capacity, and knowledge infrastructure; (3) the legal requirements and the connection with EU regulation, policy and directives; and finally (4) the financial re- 
Table 1. Overview of adaptation measures selected by the research sites.

\begin{tabular}{|c|c|c|c|c|}
\hline Research site - climate risk & $\begin{array}{l}\text { Technical infrastructure mea- } \\
\text { sures }\end{array}$ & Blue/green measures & Behavioural measures & $\begin{array}{l}\text { Socio-economic analy- } \\
\text { sis applied (also see } \\
\text { Fig. 1) }\end{array}$ \\
\hline $\begin{array}{l}\text { Wupper River basin, Germany } \\
\text { Insufficient reservoir storage } \\
\text { due to drought }\end{array}$ & $\begin{array}{l}\text { Water transport between reser- } \\
\text { voir catchments } \\
\text { Alternative water source (hori- } \\
\text { zontal well) }\end{array}$ & & $\begin{array}{l}\text { Water-saving } \\
\text { reduction of low water } \\
\text { elevation }\end{array}$ & $\begin{array}{l}\text { Cost-effectiveness } \\
\text { analysis (CEA) }\end{array}$ \\
\hline $\begin{array}{l}\text { Flood risk due to increased pre- } \\
\text { cipitation }\end{array}$ & $\begin{array}{l}\text { Technical protection measures } \\
\text { for property } \\
\text { Alignment protection } \\
\text { Retention basin }\end{array}$ & & & $\begin{array}{l}\text { CEA with multi- crite- } \\
\text { ria analysis (MCA) }\end{array}$ \\
\hline $\begin{array}{l}\text { Veluwe, the Netherlands } \\
\text { Decreasing groundwater levels } \\
\text { due to drought }\end{array}$ & Artificial infiltration & $\begin{array}{l}\text { Land use change } \\
\text { (pine to broadleaf) }\end{array}$ & Agricultural water restrictions & MCA \\
\hline $\begin{array}{l}\text { Sorraia Valley (Tagus basin), } \\
\text { Portugal } \\
\text { Decreasing groundwater levels } \\
\text { due to drought }\end{array}$ & $\begin{array}{l}\text { Rehabilitation and modernisa- } \\
\text { tion of irrigation networks }\end{array}$ & & $\begin{array}{l}\text { Tagus water resources manage- } \\
\text { ment model }\end{array}$ & CEA \\
\hline $\begin{array}{l}\text { Troodos, Cyprus } \\
\text { Constraints on public water } \\
\text { supply and irrigation due to } \\
\text { drought }\end{array}$ & $\begin{array}{l}\text { Desalination } \\
\text { Use of treated sewage water for } \\
\text { irrigation } \\
\text { Maintenance of groundwater } \\
\text { recharge systems } \\
\text { Irrigation scheduling technolo- } \\
\text { gies }\end{array}$ & & & CEA with MCA \\
\hline $\begin{array}{l}\text { Bergen, Norway } \\
\text { Combined sewer overflow due } \\
\text { to increased precipitation }\end{array}$ & $\begin{array}{l}\text { Sewer separation } \\
\text { Safe flood ways }\end{array}$ & $\begin{array}{l}\text { Sustainable urban } \\
\text { drainage systems } \\
\text { (SUDS) }\end{array}$ & & CEA \\
\hline $\begin{array}{l}\text { Badalona, Spain } \\
\text { Combined sewer overflow and } \\
\text { flash floods due to increased } \\
\text { precipitation }\end{array}$ & Increase in sewer capacity & SUDS & Early warning system & $\begin{array}{l}\text { Cost-benefit analysis } \\
\text { (CBA) }\end{array}$ \\
\hline
\end{tabular}

quirements and the way these funds can be generated. Third, the relational layer of the framework refers to the requirements placed on the wider governance context of adaptation to climate change. This entails (1) the potential cultural or ethical issues that may support or obstruct implementation of adaptation measures and (2) the requirements with regard to public accountability, communication and participation.

Based on this three-layer framework, a questionnaire was developed to assess each individual measure selected by the CoPs. The questions address the different layers and their elements. Examples of questions are as follows. Which (constellation of) actors should be involved in the development and implementation of the adaptation measure? Are the necessary actors currently involved sufficiently? Which cultural or ethical issues either support or obstruct the implementation of the adaptation measure? The questionnaires were filled in by the research partners or in a collaborative effort with experts and local stakeholders.

\subsection{Application in the Badalona case}

Following the methodology outlined above, three adaptation measures were selected for the Badalona research site with the objective of reducing urban floods and CSOs or reducing the impact thereof. These include conventional urban drainage grey infrastructure (e.g. new or larger drainage conduits, new detention tanks, new surface drains), the development of sustainable urban drainage systems (SUDSs) and the implementation of an early warning system (EWS).

For each one of the adaptation measures a governance assessment was performed by following the expert analysis of the three-layer framework. The results of the analysis demonstrate that (1) the structural measure (increase in sewer capacity) meets the knowledge and legal requirements (this measure was already included in the drainage master plan of Badalona for 2012) but does not have the financial, organisational and relational requirements for its implementation; (2) the SUDS development meets the technical and relational requirements (it has quite a lot of support given it is a "green solution") but does not meet the financial, legal and organisational requirements to foster its implementation; (3) the 
early warning system meets almost all the requirements except from the relational layer regarding public accountability, communication and participation.

This governance assessment (together with the socioeconomic assessment explained next) has allowed the Badalona City Council to have a clear roadmap to support decisions towards urban adaptation.

\section{Analysis of socio-economic implications}

\subsection{Guidance in selecting fitting analysis frameworks}

Achieving a viable adaptation to climate change is a complex task that is highly dependent on factors such as the financial means of involved stakeholders and the social impacts of the implementation of a measure. For decision makers it is key to define all necessary indicators and acquire the necessary data for the evaluation. Guidance is needed to find the framework that best fits the specific case, depending on the need to include not only monetary but also non-monetary decision indicators (Markanday et al., 2019; Dogulu and Kentel, 2015).

Within the BINGO project a toolbox was compiled that summarises the state of the art of suitable methods for evaluating and comparing alternative strategies and measures for climate change adaptation (Koti et al., 2017). This toolbox has been used as a background framework to analyse and prioritise fitting risk reduction measures for the six research sites, customised to local stakeholders' needs. The work conducted in the BINGO project resulted in the preparation of a decision tree that supports stakeholders to identify suitable assessment methods, depending on their requirements and preferences for the analysis process. Complementing the comprehensive BINGO toolbox, the decision tree in Fig. 1 focuses on those analysis frameworks applied in the BINGO case studies.

The application of the decision tree presupposes the definition of potential adaptation measures. This is due to the fact that the provided methods aim to support the analyst in prioritising a set of potential adaptation measures. The work conducted in the BINGO case studies showed that the nature of potential adaptation measures (e.g. infrastructural measures, behavioural measures) can have a major influence on the requirements of the analysis methods and relevant indicators, underlying the need for a case-specific analysis method. Furthermore, a risk assessment of expected climate change hazards and their magnitude needs to be conducted beforehand. This is important in formulating a baseline (expected future without any adaptation measure). In this way the risk reduction potential compared to that baseline can be assessed for all alternative adaptation measures, in order to evaluate the potential risk reduction of each measure. This is a mandatory data set to compare alternative adaptation measures with one of the methods presented in the framework above. This risk reduction potential should be used as a primary indicator. For example, in the application of a cost-effectiveness analysis (CEA) it can serve as input to compare the costs to the risk reduction effectiveness.

In selecting an evaluation framework by using the decision tree, the participation of all stakeholders that are affected by the adaptation measures turned out to be of high importance. These stakeholders might be water authorities, local or regional governments, NGOs, farmers, or local residents. The BINGO case studies showed the importance of stakeholders getting the chance to express their points of view and major concerns. This holistic integration of stakeholder perspectives enabled the definition of sets of indicators for prioritisation of adaptation measures, and that ensured the eventual acceptance of the results by all stakeholders. An omission of this broad stakeholder participation might lead to a lack of stakeholders' acceptance of the analysis results and thus to major barriers in the implementation of the adaptation measures. Limitations in the final choice of an evaluation framework may arise due to insufficient data availability, e.g. because required data do not exist or because the effort to get the required data is incommensurate with the benefits gained.

The following sections briefly highlight why and in which case studies of the BINGO project the decision support frameworks have been applied. This is not a comprehensive presentation of the results, since this would exceed limits of this article. Details can be found throughout the documentation in BINGO project reports (http://www.projectbingo.eu/ resources, last access: 8 July 2021).

\subsection{Cost-benefit analysis}

A CBA helps to obtain a rank of available options in monetary terms. It is a commonly used approach to prioritise flood risk reduction measures for climate change adaptation (Penning-Rowsell et al., 2010; Zhou et al., 2012). Costs represent the resources necessary to implement a certain measure. In this context, benefits account for the expected reduction of monetary damages brought by the measure implementation. In addition, co-benefits can be included for measures that improve ecosystem service provision, such as green infrastructure, which are evaluated in monetary terms by available valuation methods (OECD, 2018; Gerner et al., 2018; Hanley and Barbier, 2009).

A CBA was conducted for the Badalona case study, due to suitability with the data available and general interest among stakeholders. The costs of the measures under assessment contain (1) initial investments, included gradually in a linear trend following the assumptions of future implementation times; (2) operating costs for the time horizon of the analysis (set until 2100); and (3) rehabilitation and disposal costs, considering technical assumptions on the duration of the assets.

Benefits were assessed using the avoided cost methods, consisting of the estimation of the difference between esti- 


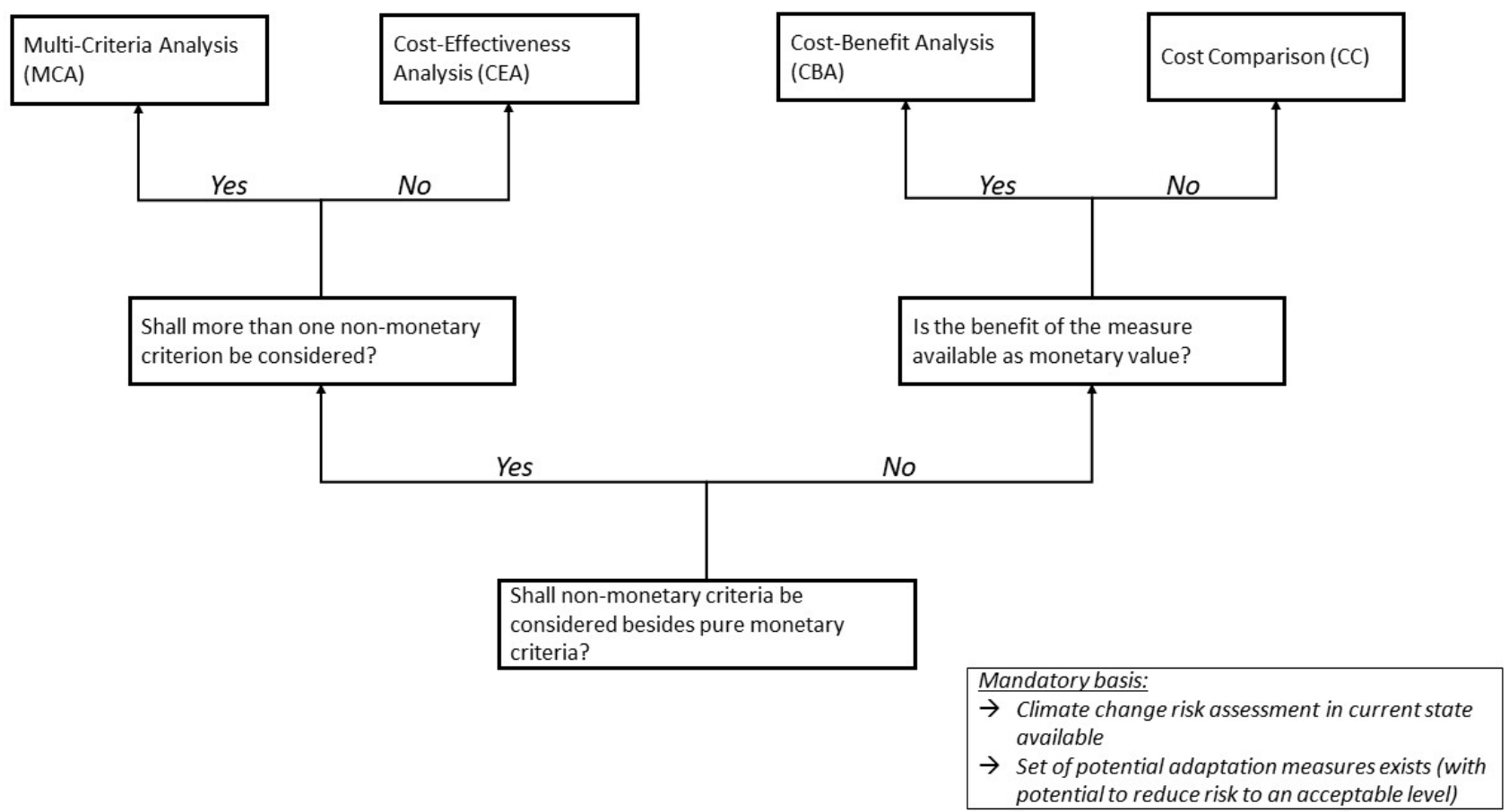

Figure 1. Decision tree supporting the definition process of a fitting analytical framework to evaluate socio-economic implications of climate change adaptation measures.

mated damages in the baseline scenario and in each of the alternative scenarios. Expected annual damage (EAD) was used as an indicator (Martinez-Gomariz et al., 2018) for flood damages, calculated for Badalona using historical flood damage data provided by the National Reinsurance Consortium (Consorcio de Compensación de Seguros). In addition, for the green roof and other green areas proposed as measures, ecosystem service benefits were identified as regulating (air quality and temperature control), supporting (habitat creation) and cultural (aesthetic) services. Monetisation of the changes on the environmental variables were estimated using market prices for the marketed items (e.g. reduction of electricity consumption from temperature control) and also non-market prices for those items that do not have a market for trade (e.g. increase in property value after green roof implementation). For non-market prices, the benefit transfer method has been applied, using reference studies and adapting the values in economic and size terms. For more details on the methodologies and results, please refer to the deliverable D5.3 of the project (Strehl et al., 2019a).

\subsection{Cost-effectiveness analysis}

The core idea of a CEA is to relate the costs of a measure to its effectiveness, like the technical performance (Levin and McEwan, 2001). Both key figures, the costs and the effectiveness, which is measured with a suitable indicator, need to be quantified to calculate the ratio. Within BINGO, a CEA was used in the case study of the Große Dhünn reservoir (Wup- per River basin). The reservoir, operated and owned by the Wupperverband (regional water board), usually stores up to $81 \mathrm{Mm}^{3}$ of water used for drinking water production, supplying up to 1 million people. In this case the risk assessment conducted in the project pointed out the potentially hazardous event of more than $1000 \mathrm{~d}$ with an insufficient reservoir water storage (defined as less than $35 \mathrm{Mm}^{3}$ water storage) in the worst-case decadal climate change projections. Therefore, the focus of this case study was to explore infrastructural and non-infrastructural adaptation measures that reduce the risk to an acceptable level.

In this particular case, effectiveness was measured by a non-monetary indicator, namely its technical performance, which was defined as the additional amount of available water per year. The Wupperverband had the capacity to simulate the additional amount of water based on the reduction of the low water elevation (non-infrastructural measure) and by a transfer pipeline from the so-called Kerspe reservoir to the Große Dhünn reservoir (infrastructural measure). Moreover, the additional water availability by a new horizontal well (infrastructural measure) and by water-saving devices coupled with water use restrictions as emergency action (non-infrastructural measure) could be estimated. The data availability allowed a cost estimation for all four measures. Thus, a cost-effectiveness analysis was the best-fitting decision support method in this case, offering the possibility to rank technically and/or organisationally feasible risk reduction measures by their cost-effectiveness ratio, advising the 
Wupperverband and other regional stakeholders in the prioritisation of climate change adaptations for their regional situation. More details can be found in Strehl et al. (2019a).

\subsection{Multi-criteria analysis}

An MCA describes a class of analysis methods that consider a variety of different criteria (synonym: indicators) to achieve a prioritisation of the potential measures. A common application is the weighted sum method. Here, first the stakeholders affected by the potential adaptation measures have to agree on a set of relevant indicators to evaluate the impacts of the different measures. Afterwards the stakeholders have to give a weight to each indicator. In the subsequent step each indicator is evaluated by the stakeholders with respect to its manifestation for each respective measure, e.g. by applying a scale from 1 (negative manifestation) to 5 (positive manifestation). Finally, the score for each measure is determined by summing up the products of the weighting and the evaluation score of each measure. These final scores serve as a ranking of the measures (Carrico et al., 2014).

This method was applied in the Veluwe case study. The Veluwe is a region in the Netherlands dealing with hazards of long-term droughts and warming/heat stress. To reduce the risks connected to these hazards, three potential adaptation measures were identified, namely the reduction of areas covered by pine trees, the implementation of artificial surface water infiltration and agricultural water restrictions. As a separate cost-effectiveness analysis was conducted in the Veluwe case, an MCA was chosen as second decision support that focused on 19 different non-monetary indicators that the group of relevant stakeholders agreed on. This methodology enabled a focused investigation of the manifestation of different non-monetary indicators besides the costeffectiveness analysis, allowing us to make a well-founded and holistic decision for or against the respective adaptation measures (Strehl et al., 2019a).

\subsection{Cost comparison}

Cost comparison (CC) is a dynamic approach used to compare the costs. Investment expenditures as well as operational expenditures for implementing and operating an adaptation measure are accounted for along the lifetime of a measure, also minding discounting (Götze et al., 2015; DWA, 2012). The advantage of a CC in general is that it allows a straightforward comparison of adaptation measures by one single common indicator. Thus, this method is a viable approach to support decision making in climate change adaptation if only cost data are available for potential adaptation measures, or if the costs are the most important indicator and other indicators are negligible.

Within the BINGO case studies, no sole $\mathrm{CC}$ was conducted as the data availabilities in all case studies allowed a more complex analysis, incorporating more than one single indi- cator for decision support analysis. However, the underlying methodology for a CC was used in many of the case studies, e.g. in the case study for the Große Dhünn reservoir (Wupper River basin) to calculate the annual costs for adaptation measures.

\subsection{Combining frameworks}

The decision tree explained above serves as a guide that is suitable for a variety of cases where decisions for or against certain adaptation measures need to be made. However, sometimes a combination of analysis frameworks might be necessary or desired. Within the BINGO project, this was essential for the case study of the Wupper River basin. The spatial boundaries of that case study covered an area of approx. $8 \mathrm{~km}^{2}$ around a small urban water course called the Mirke creek. The area is known as an endangered flood zone (MKULNV, 2015), and recent flood damage events triggered the urgency of involved stakeholders to act since flood risk might also be aggravated with further climate change in the future. The aim of the case study was to compare potential flood risk reduction measures at several so-called critical hotspots along a $6 \mathrm{~km}$ long course of the creek. The explored measures needed to be ranked by their cost effectiveness in order to advise stakeholders where to spend time and financial resources first (Strehl et al., 2019b).

To capture all relevant socio-economic details, the customised approach for Wuppertal had to combine some of the frameworks mentioned in Fig. 1 above. In the Wupper River basin case, stakeholders stated from the beginning of the project that non-monetary indicators are also relevant for this case study. However, as stated above, the primary aim was to rank the solutions in order to guide stakeholders on how to spend time and financial resources wisely, beginning at a hotspot with the best cost effectiveness. This is why a CEA was combined with an MCA framework.

The MCA framework followed in the Wupper River basin case study was aligned to the so-called analytical hierarchy process (AHP) based on Saaty (2008) and Saaty (1987). Here, at first a weighing of the indicators was given by the stakeholders by pairwise comparisons of the indicators, followed by an evaluation of the indicators' manifestations themselves. Both values per indicator were afterwards combined to a final value that indicates the respective measure's effectiveness in non-monetary terms. The resulting single value was related to the costs for each measure (as calculated by the principles of a $\mathrm{CC}$ ). Details on the subsequent approach and results of the case can be found in the BINGO D5.3 report (Strehl et al., 2019a). 


\section{Social justice analysis}

\subsection{Why a social justice analysis?}

Social justice and equity principles have been highlighted by the IPCC (2018) as key aspects of a climate-resilient development of societies. Adaptation to climate change is difficult to regulate because the causes and effects of a changing climate are spread both geographically and in time. For policy-making on climate adaptation to be legitimate and effective, it has to take justice and equity principles into account (Gupta, 2005; Caney, 2005b). Adaptation policies also contribute to human well-being and social capital and increase the overall adaptive capacity of societies (Reckien et al., 2018).

Until today, the debate on social justice and climate change has mainly centred on the recognition of responsibility for global climate change (Pielke et al., 2007), inter-generational justice (Caney, 2005a) and distributional justice, especially in the context of vulnerability to impacts of climate change (Adger 2006; Breil et al., 2018). It is only recently that social justice has emerged as a central concept to guide decision making for adaptation policy. In the face of climate change, the scope of the transition ahead calls for a high degree of support from all parts of society. The successful implementation of adaptation action thus depends on transparent and legitimate decision-making processes as well as a systematic consideration of equity principles (Patterson et al., 2018). A social justice analysis of adaptation measures, especially with an advanced methodology to introduce the topic into adaptation decision making, has great potential to assess the probable acceptability of proposed measures, to inform their context-adequate design and to enhance the legitimacy of the planning process with a view to the long-term support by the wider public.

\subsection{The concept of social justice in BINGO}

There is not a commonly agreed definition of social justice or equity in the context of adaptation (Breil et al., 2018), and the prioritisation of principles and values varies according to the specific regional context (EEA, 2018). In essence, social justice theorises about fair allocations of burdens and benefits among different members of a society (Rawls, 1971). According to Miller (1999) social justice thus concerns the question of "how the basic structure of a society distributes advantages and disadvantages to its members". These distributions are often based on, and legitimised through, "distributive" or "equity" principles (Buchanan, 1972; Cook, 1987). The BINGO social justice analysis seeks to map the distributions of costs or negative impacts and benefits of the adaptation measures among different actors or groups in society in the specific context of each research site. This was done using a standardised questionnaire (see Fig. 2). Participants also received a short introduction paper, highlighting the concept of social justice to them as well. The questionnaire was developed based on three equity principles generally distinguished in the environmental-philosophical literature (Shue, 1999; Low and Gleeson, 1998; Paavola and Adger, 2002; Ikeme, 2003; Anand, 2004). (1) The egalitarian principle is based on Mill's and Bentham's utilitarian "greatest happiness principle". Distributions aim to maximise the positive effects and minimise the negative effects for society as a whole. An example of this principle in adaptation governance is the upcoming international weather insurances and bonds, which pay out after a certain weather disaster irrespective of the needs of the victims (Dlugolecki and Keykhah, 2002). (2) The solidarity principle aims to neutralise "involuntary inequalities" between people. Distributions follow Rawls' "maximin" principle which involves maximising the well-being of those who are worst off. A practical example of the operation of this principle in adaptation governance is the United Nations Adaptation Fund that finances adaptation projects in developing countries (Person and Remling, 2014). (3) The deontological principle is based on Kant's notion that people are rational and act intentionally and can therefore be held responsible for their choices and actions. Nozick elaborated on this notion in his "entitlement theory", which holds that any "patterned" redistributions focused on outcomes are unjust and (re)distributions should always put individual rights and liberties at the basis. The "polluter pays" principle is a practical example of this principle (Tol and Verheyen, 2004).

As the evaluation of social justice is highly context dependent, the analysis does not present a conclusive result for each measure but rather presents a qualitative summary of distributional impacts for decision makers to consider in addition to the rating which is produced in the socio-economic assessment.

\subsection{The application of social justice analysis in BINGO - the Badalona case study}

In the BINGO case study of Badalona, the application of the social justice analysis for the three selected adaptation measures shows the following. (1) All adaptation measures will have positive impacts on Badalona's citizens. The general public will benefit from the reduction of flooding and combined sewer overflows and the social perception in the municipality's efficiency will increase. (2) None of the adaptation measures are likely to incur negative side effects; on the contrary, the implementation of nature-based solutions will incur social co-benefits such as enhanced public amenity, enhanced air quality, increase in ecosystem services and the reduction of the "heat island effect". (3) Regarding equity principles, both the deontological and egalitarian principles may apply in the case of climate change adaptation given that, on the one hand, Badalona's citizens are paying for the proper performance of the urban drainage system and at the same time 


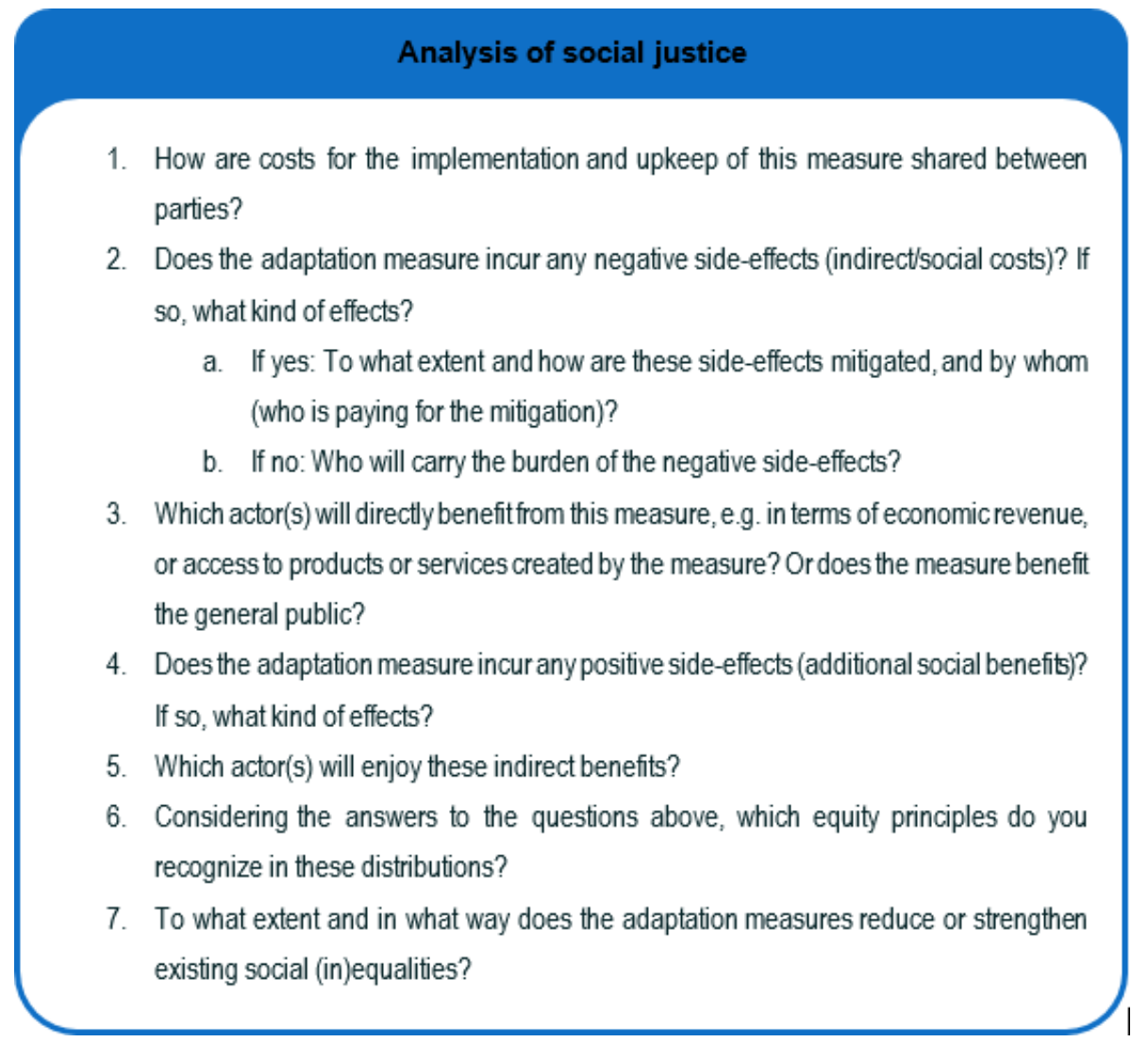

Figure 2. Questionnaire for social justice analysis.

the society as a whole receives the positive consequences of such adaptation.

\subsection{Limitations}

Pre-existing inequalities or specific vulnerabilities of certain groups of the respective municipalities could only be considered to a limited extent (question 7 of the questionnaire). However, the analysis of specific social vulnerabilities at the level of the municipality is advisable when designing adaptation measures as well as the participation of vulnerable groups in the planning process to ensure that the contextual and procedural equity are also taken into account (Breil et al., 2018).

\section{Summary of results}

In total, 22 measures were selected and analysed using the methods described above (Table 1). A majority of measures are technical or "grey" measures. This may be explained by the familiarity of the stakeholders and end users with this type of measure. The governance analysis shows that the knowledge and administrative resources for implementation of these measures are present at the sites, and implementation generally does not require the involvement of a broad range of stakeholders. Also, the effectiveness of these measures can often be modelled and is less uncertain than for instance behavioural measures. This is in line with Dhakal and Chevalier (2017), who find that, in the case of urban storm water management, technical solutions remain preferable throughout the world. However, the socio-economic analysis shows that these technical infrastructure measures are often expensive, particularly when compared with blue-green solutions or behavioural measures.

In the case of Badalona, the grey infrastructure proposed has the highest level of risk reduction but is also much more expensive than the SUDS and the EWS. In fact, the costbenefit analysis shows that the investment and operational costs are not compensated for by the socio-economic benefits considered. The proposed SUDSs have a lower potential for flood and CSO risk reduction (also because the measures analysed only covered a small area of the city), but the improvements they bring, for instance to habitat creation, and enhanced aesthetic and recreational value (Locatelli et al., 2020) give them a higher net benefit. The EWS was the most cost-effective measure, significantly reducing flood risk.

When the measures are compared by their governance needs, we see a different picture. In Badalona, the measures 
that propose an increase in sewer capacity are part of an already existing urban drainage master plan. That means that the knowledge and competencies to implement these measures are readily available. This is labelled by Dhakal and Chevalier (2017) as a "pro-grey arrangement". The main barriers to implementation are funding, political decision making and disturbance due to construction works. While the SUDSs require a smaller budget, there is limited experience on how to implement them, and technical expertise and standards/guidelines are currently lacking, although relevant knowledge can be obtained from regional examples or local research partners. SUDSs require the collaboration of a broad range of stakeholders, which requires coordination by the Badalona City Council. This makes implementation significantly more complicated than the proposed technical measures. These barriers are all acknowledged in other cases as well (Dhakal and Chevalier, 2017). The governance needs for the EWS are mostly met; the main challenge is to develop and implement the required protocols for the response to the "warnings" that the EWS gives.

In terms of social justice, as stated above, all measures have a positive impact on Badalona's citizens due to the decrease in the risk of floods and CSOs. The SUDSs have an increased benefit, due to their many positive side effects, but some of them are local and depend on where the measures are implemented.

The case of Bergen shows similar results. The sewer separation (a traditional engineering measure) shows the highest potential for risk reduction, particularly in cases of extreme rainfall. However, they are also very expensive in relation to the risk reduction achievable. The proposed SUDS measures are relatively low priced compared to their overall risk reduction potential, but they do not have the potential to reduce the risk of extreme events. When combined with using the roads as safe flood ways (a clever way of repurposing the grey infrastructure), they are able to handle peak flows in urban drainage at lower costs than sewer separation. The combination of blue-green-grey measures has been proven successful in other studies as well (Alves et al., 2020; Depietri and McPhearson, 2017).

In the case of Bergen, all the governance needs for implementation of sewer separation are met. With regard to SUDSs, there is still additional knowledge required on the performance of SUDSs in cold climates. The BINGO project was instrumental in involving the required stakeholders and so meeting the organisational needs. However, there were too few incentives for private property owners to implement the required measures (see also Dhakal and Chevalier, 2017). This can be circumvented by first implementing the SUDS at municipally owned properties. The implementation of safe flood ways is a less traditional technical solution. It adds a new functionality to roads that fall outside the responsibility of the road authorities and thus require coordination between different municipal authorities, an example of fragmented governance (Dhakal and Chevalier, 2017). Also, the broader impact on public safety when running water with high velocity through the streets needs to be assessed (Skrede et al., 2020).

All measures in Bergen benefit the general public because of the reduction of the risk of CSOs. As in the Badalona case, the SUDSs can provide many side benefits that have additional positive impacts. Negative side effects mostly involve construction and maintenance activities and resulting disturbances. Most measures are financed at the municipal level, reflecting the egalitarian or solidarity principle. SUDS or sewer separation implemented at private properties has to be financed privately, following the "polluter pays" principle (Strehl et al., 2019a). In the Veluwe case, the artificial retention measure, which involves constructing a large water transportation pipe from a nearby lake to the Veluwe, is the most expensive measure. It is also the measure with the highest potential for risk reduction, in this case measured as the additional groundwater recharge in the Veluwe groundwater system (approximately $30 \mathrm{Mm}^{3} \mathrm{yr}^{-1}$ ). The additional recharge for the green measures (change in vegetation) ranges from $2-20 \mathrm{Mm}^{3} \mathrm{yr}^{-1}$, but at much lower costs. Agricultural water restrictions are less expensive than the other measures. Most expenses go to helping farmers change their farming practices (or buying them out), since water restrictions will force them to change crops. However, the amount of water saved is relatively small $(0.2-$ $\left.0.3 \mathrm{Mm}^{3} \mathrm{yr}^{-1}\right)$.

At the Veluwe, the implementation of artificial retention is relatively easy, because the required knowledge is available and the required coordination between actors is limited and can be achieved through existing institutions. The implementation of land use change is much more complicated. It requires the collaboration between stakeholders outside of current arrangements and with diverging interests. The BINGO $\mathrm{CoP}$ has already been successful in establishing this cooperation. More importantly, changing land use has a huge impact on public opinion, since the Veluwe is well protected (Natura 2000) and a cherished spot for recreation. Changing its vegetation at the required scale would require a public debate on forest management at the national level (van Alphen et al., 2019). Agricultural water restrictions require a locally embedded stakeholder process to be initiated, involving farmers, municipalities, water authorities and the province. It requires farmers to change their crops and farming practices, which are often considered part of the cultural heritage as well.

Artificial infiltration improves the sustainability of the drinking water supply and helps preserve the groundwater system. These benefits are distributed equally among water users in the region, who, through fees, also bear the costs. The negative side effects are mostly a decrease in attractiveness of the environment due to additional water (and energy) infrastructure. These negative effects disproportionally impact people who live near these infrastructures. Mitigation activities include minimisation of visibility and ecological effects. Land use change has a number of positive 
effects (sustainable drinking water supply, preservation of groundwater system, a more diverse and robust landscape, increased biodiversity) that impact the general public. Cost for these measures is borne mostly by land owners, who will be compensated by either the province or through water fees. Negative effects mostly have to do with the loss of wildlife and plants specific to pine forests (although overall bio-diversity will increase). During the transition period, tourism entrepreneurs may induce losses due to intensified foresting activities (Strehl et al., 2019a). For the measure agricultural water restrictions, farmers affected by the measure would carry the major burden, but would be compensated by the regional or national government for loss of production capacity. The local groundwater supply and natural environment are positively affected, which directly benefits land owners, local inhabitants and tourists.

In the case of Cyprus, the CEA shows that the most cost-effective measure is the maintenance of groundwater recharge systems (in this case check dams), yielding a $1250 \mathrm{~m}^{3}$ groundwater recharge per euro invested, compared to treated sewage water for irrigation $\left(32.6 \mathrm{~m}^{3}\right.$ recycled water used per euro invested), desalination $\left(1.5 \mathrm{~m}^{3}\right.$ desalinated water consumed per euro invested) and irrigation scheduling technologies $\left(0.90 \mathrm{~m}^{3}\right.$ water savings per euro invested). For the irrigation sector, the irrigation scheduling technologies measure had the highest MCA weighting score (13.5) compared to the treated sewage water option (12.1). For the domestic water supply sector, groundwater recharge systems received the highest final MCA score (14.6) compared to the use of water desalination (13.3) (Strehl et al., 2019a).

According to the governance needs analysis, the implementation of this maintenance scheme mainly requires better coordination between the water authority and the local community councils. Structural, institutional and political rigidities negatively affect the adoption of irrigation scheduling technologies in Cyprus. The lack of political will to charge irrigators with water prices that cover the full costs, i.e. financial, environmental and resource, does not provide an incentive to invest in water-saving technologies (van Alphen et al., 2019). Giannakis et al. (2016) suggest that the low irrigation water price elasticities, the ageing and lower training levels of farming population, the small farm size, and the low level of farm investments also impede the uptake of irrigation scheduling technologies. Support for farm training schemes, including issues such as water conservation and climate change adaptation, could improve the skills of the farmers and foster the adoption of new technologies (Giannakis and Bruggeman, 2015, 2018; van Alphen et al., 2019).

It follows from the governance needs analysis that the use of treated sewage water for irrigation could be implemented relatively easily. However, the total benefit is small, considering that only $6 \%$ of the farmers have access to this source. Also, the long-term effects of possible contaminants are yet unknown. For desalinisation the key governance challenge is financial viability. Local households will pay a higher price for the desalinated water. Yet, as community councils will be responsible for selecting the source of water, there are concerns regarding the prioritisation of a cheaper source (van Alphen et al., 2019).

All four measures proposed in the Cyprus case study are financed at least in part by the sectoral groups/communities that benefit directly and/or indirectly. Irrigation scheduling technologies and the maintenance of groundwater recharge systems have potential side effects which benefit the general public as they increase the qualitative and quantitative state of the groundwater system. Desalination and the use of treated sewage water for irrigation only benefit specific groups of water users, namely the households of the downstream communities of Peristerona watershed (desalination) and the farmers that have access to the treated waste water. Also, they have notable negative side effects (impact of emerging contaminants, carbon emissions and brine discharges) which burden the general public and future generations (Strehl et al., 2019a)

In the first Wupper River basin case (insufficient reservoir storage due to drought), it was found that the technical infrastructure measures are very expensive compared to the behavioural measures, also in relation to the level of risk reduction. The reduction of low water elevation (which effectively reduces the outflow from the reservoir) is by far the most cost-effective measure (EUR $0.001 \mathrm{~m}^{-3}$ ). The water-saving scheme is not expensive, but the effect on the capacity of the reservoir is relatively low, and so is the cost effectiveness (EUR $0.194 \mathrm{~m}^{-3}$ ). Water transportation (EUR $0.040 \mathrm{~m}^{-3}$ ) and the horizontal well (EUR $0.054 \mathrm{~m}^{-3}$ ) rank in between. It was noted, however, that these infrastructural measures may be needed as a risk buffer in the future, since they provide redundant capacity.

With regard to the governance needs, the reduction of low water elevation is also the easiest measure to implement, with most of the governance needs being met at the research site. The main concern is the effect on the downstream ecology when the outflow of the reservoir is reduced. The technical infrastructural measures in this case are much harder to implement. To build the transfer pipe between the two catchments, water authorities and the environmental agency should be involved, as well as the property owners affected by the route. It also requires setting legal standards and assessing the technical feasibility and environmental impact. The same goes for implementing a new abstraction well (horizontal well). An additional barrier for that measure is the potential change in water quality (harder water) due to mixing of sources.

Reduction of low water elevation enhances social justice by securing the water supply to the general public, without increasing the price of water. The main negative side effect is a reduced flow passing the dam, leading to a decrease in energy production and potential decline of ecological quality. This also affects the general public. The substitution with an alternative water source may increase existing inequali- 
ties since it increases the price of water, which disproportionally impacts low-income groups. The same goes for the water transport between catchments, with the addition that it negatively impacts the property owners near the infrastructure. To the extent that these owners will be compensated by the Wupper Association, the cost will be carried by the general public. Finally, the pipe/channel route can have a negative impact on the environment and landscape, which impacts the general public.

For the second Wupper River basin case (flood risk due to increased precipitation) three technical measures were analysed. The retention basin is the most expensive measure (EUR $88 \mathrm{kyr}^{-1}$ ), but it also performs best in terms of risk reduction. Alignment protection (EUR $10 \mathrm{k} \mathrm{yr}^{-1}$ ) and protection measures for property (EUR $3 \mathrm{kyr}^{-1}$ ) have a much smaller risk reduction effect, about 10 to 15 times smaller. Since these results are calculated for a specific scenario, it cannot be assumed that just increasing the investment in the latter two protection measures will yield the same risk reduction as the retention basin.

According to the governance analysis, all requirements for implementing the retention basin are in place. With regard to the technical protection measure for property, one of the barriers for implementation is convincing the property owners to take action. Support and funding need to be coordinated between public services and property owners. Flood protection is considered a public service instead of a (partially) private responsibility. When this is the case, it does not encourage private investment (Geaves and Penning-Rowsell, 2016). In the case of alignment protection, this is indeed a matter of public action, where land may be acquired from property owners, but no investment from their side is necessary.

From the social justice analysis, it follows that the retention basin will benefit people downstream of the basin, while property owners above the endangered areas have the basin built on or near their properties. The basin will be financed by the Wupper Association, but property owners may face decreasing value of their properties because of negative environmental impact or decreasing aesthetics. This can be mitigated by an appealing design and environmentally friendly construction of the basin. A positive side effect of the basin that benefits the broader public is the improvement of water quality due to a reduction of direct run-off into natural streams. Protection measures for property are generally paid for by the property owners, who also reap the benefits of reduced flood risk. In the case of municipal buildings, the municipality has the opportunity to embellish public spaces by choosing an appealing design. The alignment protection will most likely be financed by the Wupper Association, as the measure benefits the general public. In the case property owners bear the costs, this will likely lead to increased social inequalities.

In the Sorraia Valley in Portugal, the technical measures involve the rehabilitation and modernisation of existing irrigation networks, which consist of a canal, a transport and distribution system, and a secondary irrigation system. Improving the canal is not the most cost effective in terms of cubic metres of water saved, but it is in terms of impacted area. Improving the transport and distribution system and the secondary irrigation system only affect a small area and need to be replicated in other areas to reach the same impact as improving the canal (Strehl et al., 2019a). The Tagus water resources management model has the potential to be very cost effective, but this is dependent on the level of use the water authority will promote. This is also the most important challenge with regards to the governance needs. Implementing the water resources management model requires a shift from a top-down management approach to a more networkoriented governance model. This requires an integrated approach to water resource management and the participation of a broad range of actors. The rehabilitation and modernisation of the irrigation networks pose no specific governance challenges, apart from acquiring funding for the investments.

From the social justice analysis, it follows that the rehabilitation and modernisation of irrigation networks mainly benefit the farmers, who also pay for the measures. To alleviate the financial burden, they can apply for funding. The assured agricultural sustainability in the region benefits a broader public as well. The water resource management model helps to better plan and manage water resources in the Tagus river basin, which benefits the general public. The costs are borne by the water authorities and then allocated to all water users through a tax or a fee.

\section{Conclusions}

The application of the BINGO approach has been successful in generating decision-relevant outcomes for developing adaptation strategies at the research sites. The governance analysis allowed to stakeholders to identify gaps in the governance needs to implement measures and to prepare steps to fill those gaps. The outcomes of the socio-economic analysis allowed stakeholders to prioritise measures by their cost effectiveness, cost-benefit ratio or performance on a broader range of criteria. Sometimes this yielded surprising results, such as the high cost effectiveness of check dams maintenance in the case of Cyprus. Finally, the social justice analysis can help stakeholders choose a proper financing mechanism that fits the desired principle (solidarity, egalitarian, deontological) and gives a first indication of how positive and negative impacts are distributed over different groups. Although the research sites were very different, in both their challenges and their socio-economic and institutional context, the approach presented in this paper yielded useful results in all cases. This supports the transferability of the approach to other cases in Europe.

However, we can identify specific benefits and limitations for each of the analyses (Table 2). The main benefit of the governance analysis is that it provides a systematic overview 
Table 2. Assessment of the applied analyses.

\begin{tabular}{|c|c|c|}
\hline BINGO analysis & Benefit & Limitation \\
\hline Governance analysis & $\begin{array}{l}\text { Provides systematic overview of requirements } \\
\text { and whether they are met; takes into account } \\
\text { broad range of factors, not only finances and } \\
\text { technical capability. }\end{array}$ & $\begin{array}{l}\text { Method itself does not provide standards in } \\
\text { whether requirements are sufficiently met; } \\
\text { relies on self-reporting by researchers and } \\
\text { stakeholders. }\end{array}$ \\
\hline Socio-economic analysis & $\begin{array}{l}\text { Helps to structure decision-relevant information } \\
\text { about adaptation alternatives, focusing on mea- } \\
\text { surable outcomes of each option; } \\
\text { applied science offers straightforward methods } \\
\text { to quantify or at least rank relevant indicators } \\
\text { affecting costs and benefits from a socio eco- } \\
\text { nomic point of view; } \\
\text { methods for a socio-economic analysis are flex- } \\
\text { ible to integrate the scenario based thinking of } \\
\text { climate change projections. }\end{array}$ & $\begin{array}{l}\text { Limitations arise with data availability; } \\
\text { in cases with very broad decision-relevant } \\
\text { socio-economic indicators to cover, (un)reliable } \\
\text { input data for a quantitative analysis effects the } \\
\text { robustness of conclusions drawn from the anal- } \\
\text { ysis. }\end{array}$ \\
\hline Social justice analysis & $\begin{array}{l}\text { Helps to focus not only on plain outcomes } \\
\text { of adaptation, but also on distributional effects } \\
\text { among society; broadens the scope of the analy- } \\
\text { sis, eventually leading to identify additional co- } \\
\text { benefits or unbalanced burdens for stakeholders } \\
\text { of climate change adaptation measures, allow- } \\
\text { ing a better informed decision. }\end{array}$ & $\begin{array}{l}\text { Information acquisition for a social justice anal- } \\
\text { ysis relies on qualitative input, e.g. by inter- } \\
\text { views and pre-structured questionnaires as con- } \\
\text { ducted in the BINGO-project; } \\
\text { time and financial resources and available inter- } \\
\text { view partners may limit the scope of the analy- } \\
\text { sis. }\end{array}$ \\
\hline
\end{tabular}

of the requirements for implementing a certain measure, with attention to a broad range of building blocks for adequate governance. This is not limited to technical and economic aspects, but also includes cultural, communicative and legal aspects. A limitation in the way that the method was applied is that it does not provide specific thresholds for the required level of these indicators, other than reported by the researchers and stakeholders involved.

The socio-economic analysis contributed in structuring decision-relevant information on adaptation measures focusing on potential outcomes of each measure. The methods applied help to quantify and/or rank indicators affecting costs and benefits of the selected measures, from a socio-economic point of view. Moreover, the methods can be integrated in a broader scenario-based approach to assessing adaptation strategies. Limitations of the method primarily deal with the availability of data, which has a strong effect on the validity and reliability of the conclusions drawn from the analysis.

Finally, the social justice analysis gives a broader perspective than the plain focus on the outcomes of adaptation and also considers the distributional effect on different groups in society. This may result in the identification of unbalanced burdens or co-benefits, which leads to better informed decisions and helps to realise climate justice. However, in the way the method was applied, the acquisition of meaningful social justice information and derived interpretations relevant for decision makers highly relies on the interview partners. They need to have a specific knowledge of the local adapta- tion measures/options planned and the socio-economic environment.

Code and data availability. Model files and data are not provided due to the confidentiality of the data and models. Notwithstanding, in agreement with the other project stakeholders, the authors of this paper will try to address specific requests for scientific purposes.

Supplement. The supplement related to this article is available online at: https://doi.org/10.5194/nhess-21-2145-2021-supplement.

Author contributions. HJvA, CS, FV, EI, AP, SG and EB developed the methodology. All authors were involved in the research at the research sites. HJvA, CS, FV, EI, AP and SG prepared the paper with contributions from all authors.

Competing interests. The authors declare that they have no conflict of interest.

Disclaimer. Publisher's note: Copernicus Publications remains neutral with regard to jurisdictional claims in published maps and institutional affiliations 
Special issue statement. This article is part of the special issue "Integrated assessment of climate change impacts at selected European research sites - from climate and hydrological hazards to risk analysis and measures". It is not associated with a conference.

Acknowledgements. The authors wish to thank all partners and stakeholders of BINGO for their input and feedback. We specifically thank Christos Zoumides, Hakan Djuma, Marinos Eliades (The Cyprus Institute); Ayis Iacovides, Marios Mouskoundis (IACO); Maria Rafaela de Saldanha Gonçalves Matos, Ana Estela Barbosa, Maria João Freitas, Teresa Viseu (LNEC); Alberto Freitas (DGADR); Ana Luís (EPAL); Eduardo MartinezGomariz (Cetaqua); Beniamino Russo (Aquatec); Rita Andrade (SPI); Thorsten Luckner, Paula Lorza (Wupperverband); Suzanne Buil-van den Bos (Provincie Gelderland); Jan Hogendoorn, Jolijn van Engelenburg (Vitens); Juliane Koti, Andreas Hein, Leni Handelsmann (IWW); Pedro Brito (DGADR); Robert Mittelstädt (Hydrotec); Marit Aase, Magnar Sekse (Municipality of Bergen); Ashenafi Seifu Grange, Tone Merete Muthanna (NTNU); Adriana Hulsmann; and Nicolien van Aalderen. (KWR)

Financial support. This research has been supported by the BINGO European H2020 project (grant no. 641739).

Review statement. This paper was edited by Adriana Bruggeman and reviewed by two anonymous referees.

\section{References}

Adger, W. N.: Vulnerability, Global Environ. Chang., 16, 268-281, https://doi.org/10.1016/j.gloenvcha.2006.02.006, 2006.

Alves, A., Vojinovic, Z., Kapelan, Z., Sanchez, A., and Gersonius, B.: Exploring trade-offs among the multiple benefits of green-blue-grey infrastructure for urban flood mitigation, Sci. Total Environ., 703, 134980, https://doi.org/10.1016/j.scitotenv.2019.134980, 2020.

Anand, R.: International Environmental Justice: A North-South Dimension, Ashgate, Hampshire, 161, ISBN 0754638243, 2004.

Andersson-Sköld, Y., Thorsson, S., Rayner, D., Lindberg, F., Janhäll, S., Jonsson, A., Moback, U., Bergman, R., and Granberg, M.: An integrated method for assessing climate-related risks and adaptation alternatives in urban areas, Climate Risk Management, 7, 31-50, https://doi.org/10.1016/j.crm.2015.01.003, 2015.

Bhave, A. G., Mishra, A., and Raghuwanshi, N. S.: A combined bottom-up and top-down approach for assessment of climate change adaptation options, J. Hydrol., 518A, 150-161, https://doi.org/10.1016/j.jhydrol.2013.08.039, 2014.

Bojovic, D., Giupponi, C., Klug, H., Morper-Busch, L., Cojocaru, G., and Schörghofer, R.: An online platform supporting the analysis of water adaptation measures in the Alps, J. Environ. Plann. Man., 61, 214-229, https://doi.org/10.1080/09640568.2017.1301251, 2018.

Breil, M., Downing, C., Kazmierczak, A., Mäkinen, K., Romanovska, L., Terämä, E., and Swart, R. J.: Social vul- nerability to climate change in European cities - state of play in policy and Practice, (ETC/CCA Technical Paper; No. 2018/1), EEA - European Environment Agency, https://doi.org/10.25424/CMCC/SOCVUL_EUROPCITIES, 2018.

Buchanan, J. M.: Who Should Pay for Common-Access Facilities?, Public Finance, 27, 1-8, available at: https://EconPapers.repec. org/RePEc:pfi:pubfin:v:27:y:1972:i:1:p:1-8 (last access: 8 July 2021), 1972.

Caney, S.: Cosmopolitan Justice, Responsibility, and Global Climate Change, Leiden J. Int. Law, 18, 747-775, https://doi.org/10.1017/S0922156505002992, 2005a.

Caney, S.: Justice Beyond Borders - A Global Political Theory, Oxford University Press, New York, https://doi.org/10.1093/019829350X.001.0001, 2005b.

Carrico, N. J. G., Goncalves, F. V., Covas, D. I. C., Almeida, M. D. C., and Alegre, H.: Multi-criteria analysis for the selection of the best energy efficient option in urban water systems, Procedia Engineer., 70, 292-301, https://doi.org/10.1016/j.proeng.2014.02.033, 2014.

Cook, K. S.: Toward a more interdisciplinary research agenda: The potential contributions of sociology, Soc. Justice Res., 1, 5018, https://doi.org/10.1007/BF01049381, 1987.

Depietri Y. and McPhearson, T.: Integrating the Grey, Green, and Blue in Cities: Nature-Based Solutions for Climate Change Adaptation and Risk Reduction, in: Nature-Based Solutions to Climate Change Adaptation in Urban Areas. Theory and Practice of Urban Sustainability Transitions, edited by: Kabisch, N., Korn, H., Stadler, J., and Bonn, A., Springer, Cham, https://doi.org/10.1007/978-3-319-56091-5_6, 2017.

Dhakal, K. P. and Chevalier, L. R.: Managing urban stormwater for urban sustainability: Barriers and policy solutions for green infrastructure application, J. Environ. Manage., 203-1, 171-181, https://doi.org/10.1016/j.jenvman.2017.07.065. 2017.

Dlugolecki, A. and Keykhah, M.: Climate Change and the Insurance Sector: Its Role in Adaptation an Mitigation, Greener Management International, 39, 83-98, http://www.jstor.org/stable/ greemanainte.39.83, 2002.

Dogulu, N. and Kentel, E.: Prioritization and selection of climate change adaptation measures: a review of the literature, Iahr-Int Assoc Hydro-Environment Engineering Research, in: Proceedings of the 36th Iahr World Congress: Deltas of the Future and What Happens Upstream, Madrid, Den Haag, 28 June 2015-3 July 2015, 2015.

DWA: Leitlinien zur Durchführung dynamischer Kostenvergleichsrechnungen (KVR Leitlinien), Translation: Guidelines to conduct dynamic cost comparisons, DWA, Hennef, ISBN 9783941897557, 2012.

European Environment Agency (EEA): National climate change vulnerability and risk assessments in Europe, EEA Report 1, https://doi.org/10.2800/348489, 2018.

Freitas, M. J., Muthanna, T. M., Bruggeman, A., Giannakis, E., Zoumides, C., and Andrade, R.: D6.5 Guidelines designed to create, feed and enhance "win-win" collaborations between researchers and stakeholders, BINGO project report from WP6: Ensuring Excellence and Actionable Research, European Commission, Brussels, available at: http://www.projectbingo. eu/downloads/BINGO_Deliverable6.5.pdf (last access: 8 July 2021), 2018 
Garrote, L., Granados, A., and Iglesias, A.: Strategies to reduce water stress in Euro-Mediterranean river basins, Sci. Total Environ., 543, 997-1009, https://doi.org/10.1016/j.scitotenv.2015.04.106, 2016.

Geaves, L. H. and Penning-Rowsell, E.: Flood Risk Management as a public or a private good, and the implications for stakeholder engagement, Environ. Sci. Policy, 55-2, 281-291 https://doi.org/10.1016/j.envsci.2015.06.004, 2016.

Gerner, N. V., Nafo, I., Winking, C., Wencki, K., Strehl, C., Wortberg, T., Anzaldua, G., Lago, M., and Birk, S.: Large-scale river restoration pays off: A case study of ecosystem service valuation for the Emscher restoration generation project, Ecosyst. Serv., 30, 327-338, https://doi.org/10.1016/j.ecoser.2018.03.020, 2018.

Giannakis, E. and Bruggeman, A.: The highly variable economic performance of European agriculture, Land Use Policy, 45, 2635, https://doi.org/10.1016/j.landusepol.2014.12.009, 2015.

Giannakis, E. and Bruggeman, A.: Exploring the labour productivity of agricultural systems across European regions: A multilevel approach, Land Use Policy, 77, 94-106, https://doi.org/10.1016/j.landusepol.2018.05.037, 2018.

Giannakis, E., Bruggeman, A., Djuma, H., Kozyra, J., and Hammer, J.: Water pricing and irrigation across Europe: Opportunities and constraints for adopting irrigation scheduling decision support systems, Water Sci. Tech.-W. Sup., 16, 245-252, https://doi.org/10.2166/ws.2015.136, 2016.

Götze, U., Northcott, D., and Schuster, P.: Investment Appraisal - Methods and Models, Springer, London, https://doi.org/10.1007/978-3-662-45851-8, 2015.

Hanley, N. and Barbier, E. B.: Pricing Nature - Cost-Benefit Analysis and Environmental Policy, Edward Elgar Publishing, Inc., Cheltenham, Northampton, ISBN 9781845427894, 2009.

Harrison, P. A., Holman, I. P., Cojocaru, G., Kok, K., Kontogianni, A., Metzger, M. J., and Gramberger, M.: Combining qualitative and quantitative understanding for exploring cross-sectoral climate change impacts, adaptation and vulnerability in Europe, Reg. Environ. Change, 13, 761-780, https://doi.org/10.1007/s10113-012-0361-y, 2013.

Havekes, H., Hofstra, M., Van der Kerk, A., Teeuwen, B., Van Cleef, R., and Oosterloo, K.: Building Blocks for Good Water Governance. Water Governance Centre (WGC), available at: https://www.uvw.nl/wp-content/uploads/2017/11/ Building-blocks-for-good-water-governance-2016.pdf (last access: 8 July 2021), 2016.

Ikeme, J.: Equity, environmental justice and sustainability: incomplete approaches in climate change politics, Global Environ. Chang., 13, 195-206, https://doi.org/10.1016/S09593780(03)00047-5, 2003

IPCC: Summary for Policymakers, in: Global Warming of $1.5^{\circ} \mathrm{C}$. An IPCC Special Report on the impacts of global warming of $1.5^{\circ} \mathrm{C}$ above pre-industrial levels and related global greenhouse gas emission pathways, in the context of strengthening the global response to the threat of climate change, sustainable development, and efforts to eradicate poverty, edited by: MassonDelmotte, V., Zhai, P., Pörtner, H.-O., Roberts, D., Skea, J., Shukla, P. R., Pirani, A., Moufouma-Okia, W., Péan, C., Pidcock, R., Connors, S., Matthews, J. B. R., Chen, Y., Zhou, X., Gomis, M. I., Lonnoy, E., Maycock, T., Tignor, M., and Waterfield, T., World Meteorological Organization, Geneva, Switzer- land, 32 pp., available at: https://www.ipcc.ch/sr15/ (last access: 8 July 2021), 2018.

Iyalomhe, F., Jensen, A., Critto, A., and Marcomini, A.: The Science-Policy Interface for Climate Change Adaptation: the Contribution of Communities of Practice Theory, Environ. Policy Gov., 23: 368-380. https://doi.org/10.1002/eet.1619, 2013.

Koti, J., Hein, A., Interwies, E., Wencki, K., and Görlitz, S.: MS22report: Economic and social impacts of measures determined. Suitable assessment methods for the evaluation of adaptation strategies and/or measures to climate change, European Commission, Brussels, 2017.

Levin, H. M. and McEwan, P. J.: Cost-Effectiveness Analysis: Methods and Applications, Sage Publications, London, ISBN 9780761919346, 2001.

Locatelli, L., Guerrero, M., Russo, B., Martínez-Gomariz, E., Sunyer, D., and Martínez, M.: Socio-Economic Assessment of Green Infrastructure for Climate Change Adaptation in the Context of Urban Drainage Planning, Sustainability, 12, 3792, https://doi.org/10.3390/su12093792, 2020.

Low, N. and Gleeson, B.: Justice, Society and Nature, Routledge, London, https://doi.org/10.4324/9780203006689, 1998.

Markanday, A., Galarraga, I., and Markandya, A.: A critical review of cost-benefit analysis for climate change adaptation in cities, Climate Change Economics 10, 1950014, https://doi.org/10.1142/S2010007819500143, 2019.

Martínez-Gomariz, E., Gómez, M., Russo, B., Sánchez, P., and Montes, J.: Methodology for the damage assessment of vehicles exposed to flooding in urban areas, J. Flood Risk Manag., 12, e12475, https://doi.org/10.1111/jfr3.12475, 2018.

Meyer, V., Gebhardt, O., and Moreira Alves, F.: Economic evaluation of adaptation options, BASE project report D5.2, European Commission, Brussels, available at: https://base-adaptation. eu/sites/default/files/Deliverable_5_2_FINAL.pdf (last access: 8 July 2021), 2015.

Miller, D.: The principles of Social Justice, Harvard University Press, Cambridge, ISBN 9780674007147, 1999.

MKULNV: Hochwasserrisikomanagementplanung in NRW, Hochwassergefährdung und Maßnahmenplanung Wuppertal, Bezirksregierung Düsseldorf und Ministerium für Klimaschutz, Umwelt, Landwirtschaft, Natur- und Verbraucherschutz des Landes Nordrhein-Westfalen, available at: https://docplayer.org/ 58398659-Hochwasserrisikomanagementplanung-in-nrwhochwassergefaehrdung-und-massnahmenplanungwuppertal.html (last access: 8 July 2021), 2015.

OECD: Water Governance in OECD Countries: A Multi-level Approach, OECD Studies on Water, OECD Publishing, Paris, https://doi.org/10.1787/9789264119284-en, 2011.

OECD: Cost-Benefit Analysis and the Environment: Further Developments and Policy Use, OECD Publishing, Paris, https://doi.org/10.1787/9789264085169-en, 2018.

O'Sullivan, J., Pollino, C., Taylor, P., Sengupta, A., and Parashar, A.: An Integrative Framework for Stakeholder Engagement Using the Basin Futures Platform, Water, 12, 2398, https://doi.org/10.3390/w12092398, 2020.

Paavola, J. and Neil Agder, W.: Justice and Adaptation to Climate Change, Working paper no. 23, Tyndall Centre for Climate Change Research, Norwich, available at: https://www.researchgate.net/profile/Jouni_ Paavola/publication/228813871_Justice_and_Adaptation_ 
to_Climate_Change/links/Odeec52b32569b86d8000000/

Justice-and-Adaptation-to-Climate-Change.pdf (last access: 8 July 2021), 2002.

Palutikof, J. P., Street, R. B., and Gardiner, E. P.: Looking to the future: guidelines for decision support as adaptation practice matures, Clim. Change, 153, 643-655, https://doi.org/10.1007/s10584-019-02404-x, 2019.

Patterson, J., Thaler, T., Hoffman, M., Hughes, S., Oels, A., Chu, E., Mert, A., Huitema, D., Burch, S., and Jordan, A.: Political feasibility of $1.5^{\circ} \mathrm{C}$ societal transformations, the role of social justice, Curr. Opin. Env. Sust., 31, 1-9, https://doi.org/10.1016/j.cosust.2017.11.002, 2018.

Penning-Rowsell, E., Viavattene, C., Pardoe, J., Chatterton, J., Parker, D., and Morris, J.: The Benefits of Flood and Coastal Risk Management: A Handbook of Assessment Techniques, Flood Hazard Research Centre, Middlesex University, London, 98 pp., ISBN 1904750516, 2010.

Persson, A. and Remling, E.: Equity and efficiency in adaptation finance: initial experiences of the Adaptation Fund, Clim. Policy, 14, 488-506, https://doi.org/10.1080/14693062.2013.879514, 2014.

Pielke Jr., R., Prins, G., Rayner, S., and Sarewitz, D.: Lifting the taboo on adaptation: renewed attention to policies for adapting to climate change cannot come too soon, Nature, 445, 597-598, https://doi.org/10.1038/445597a, 2007.

Rawls, J.: A Theory of Justice, Harvard University Press, Cambridge, ISBN 9780674000780, 1971, rev. edn. 1999.

Reckien, D., Lwasa, S., Satterthwaite, D., McEvoy, D., Creutzig, F., Montgomery, M., Schensul, D., Balk, D., and Khan, I.: Equity, environmental justice, and urban climate change, in: Climate Change and Cities, Second Assessment Report of the Urban Climate Change Research Network, edited by: Rosenzweig, C., Solecki, W., Romero-Lankao, P., Mehrotra, S., Dhakal, S., and Ali Ibrahim, S., Cambridge University Press, New York, 173224, ISBN 9781316603338, 2018.

Saaty, R. W.: The Analytic Hierarchy Process - What it is and how it is used, Math. Modelling, 9, 161-176, https://doi.org/10.1016/0270-0255(87)90473-8, 1987.

Saaty, T. L.: Decision making with the analytic hierarchy process, International Journal of Services Sciences, 1, 83-98, https://doi.org/10.1504/IJSSCI.2008.017590, 2008.

Shue, H.: Global environment and international inequality, Int. Aff., 75, 531-545, https://doi.org/10.1111/1468-2346.00092, 1999.

Singh, C., Ford, J., Ley, D., Bazaz, A., and Revi, A.: Assessing the feasibility of adaptation options: methodological advancements and directions for climate adaptation research and practice, Climatic Change, 162, 255-277, https://doi.org/10.1007/s10584020-02762-x, 2020.

Skrede, T. I., Merete Muthanna, T., and Alfredesen, K.: Applicability of urban streets as temporary open floodways, Hydrol. Res., 51, 621-634, https://doi.org/10.2166/nh.2020.067, 2020.

Strehl, C., Bruggeman, A., Freitas, A., Petersen, A., Hein, A., Grange, A. S., Iacovides, A., Zoumides, C., Interwies, E., Martinez-Gomariz, E., Giannakis, E., Kristvik, E., Vollmer, F., Rocha, F., van Alphen, H.-J., Koti, J., Handelsmann, L., Locatelli, L., Sekse, M., Scheibel, M., Hidalga Guerrero, M., Mouskoundis, M., Aase, M., Martinez, M., Lorza, P., Brito, P., Mittelstädt, R., Görlitz, S., Buil, S., Spek, T., Luckner, T., and Muthanna, T.: D5.3 Report on economic and soci- etal impacts of the proposed measures, BINGO project report from WP5 Developing risk treatment and adaptation strategies for extreme weather events, European Commission, Brussels, available at: http://www.projectbingo.eu/downloads/ BINGO_Deliverable5.3.pdf (last access: 8 July 2021), 2019a.

Strehl, C., Vollmer, F., Hein, A., Koti, J., Scheibel, M., Lorza, P., Heinenberg, D., Mittelstädt, R., Interwies, E., and Görlitz, S. BINGO PROJECT: Selection of effective adaptation measures to weather extremes - Reducing flood risk in Wuppertal, Germany, Conference Contribution to the 4th European Climate Change Adaptation conference (ECCA), Lisbon, available at: http://www.projectbingo.eu/downloads/BINGO_ Deliverable7.9.pdf (last access: 8 July 2021), 2019 b.

Tol, R. S. J. and Verheyen, R.: State Responsibility and Compensation for Climate Change Damages - a Legal and Economic Assesment, Energ. Policy, 32, 1109-1130, https://doi.org/10.1016/S0301-4215(03)00075-2, 2004.

van Alphen, H. J., Bergsma, E., Urioc, S., Interwies, E., Görlitz, S., and Koti, J.: Portfolio of risk management and adaptation strategies available for the six research sites in BINGO, BINGO project report from WP5 Developing risk treatment and adaptation strategies for extreme weather events, European Commission, Brussels, available at: http://beta.tools.watershare.eu/bingo/ I\$/ (last access: 8 July 2021), 2017a.

van Alphen, H. J., Kristvik, E., Mouskoundis, M., Iacovides, I., Iacovides, A., Martinez, M., Sanchez, P., Russo, B., Malgrat, P., Zoumides, C., Giannakis, E., Bruggeman, A., Bergsma, E., Hulsmann, A., Koti, J., Interwies, E., Görlitz, S., and Freitas, M. J.: D5.2 Compilation report on initial workshops at the six research sites, BINGO project report from WP5 Developing risk treatment and adaptation strategies for extreme weather events, European Commission, Brussels, available at: http://www.projectbingo. eu/downloads/BINGO_Deliverable5.2.pdf (last access: 8 July 2021), 2017b.

van Alphen, H. J., Spek, T., Buil, S., Giannakis, E., Bruggeman, A., Zoumides, C., Rocha, F., Scheibel, M., Lorza, P., Kristvik, E., Merete Muthanna, T., Strehl, C., Handelsmann, L., Martinez Puentes, M., Russo, B., Interwies, E., Görlitz, S., and Petersen, A.: D5.5: Complete Report on the Assessment of the Current Situation and Recommendations for Improvement Using the Three Layer Framework, BINGO project report from WP5 Developing risk treatment and adaptation strategies for extreme weather events, European Commission, Brussels, available at: http://www.projectbingo.eu/downloads/ BINGO_Deliverable5.5.pdf (last access: 8 July 2021), 2019.

Verkerk, P. J., Sánchez, A., Libbrecht, S., Broekman, A., Bruggeman, A., Daly-Hassen, H., Giannakis, E., Jebari, S., Kok, K., Krivograd Klemencic, A., Magjar, M., Martinez de Arano, I., Robert, N., Smolar-Zvanut, N., Varela, E., and Zoumides, C.: A Participatory Approach for Adapting River Basins to Climate Change, Water, 9, 958, https://doi.org/10.3390/w9120958, 2017.

Vincent, K., Steynor, A., Waagsaether, K., and Cull, T.: Communities of practice: One size does not fit all, Climate Services 11, 72-77, https://doi.org/10.1016/j.cliser.2018.05.004, 2018.

Watkiss, P., Hunt, A., Rouillard, J., Tröltzsch, J., Lago, M., Skourtos, M., Kontogianni, A., Chiabai, A., Galarraga, I., Markandya, A., Sainz de Murieta, E., Bosello, F., Ščasný, M., Mechler, R., Havlik, P., Scussolini, P., Kuik, O., Carlos, J., and Zhu, X.: The costs and benefits of adapta- 
tion: results from the ECONADAPT project, Policy report, https://doi.org/10.13140/RG.2.1.2061.7443, 2015.

Wilby, R. L.: A global hydrology research agenda fit for the 2030s, Hydrol. Res., 50, 1464-1480, https://doi.org/10.2166/nh.2019.100, 2019.
Zhou, Q., Mikkelsen, P. S., Halsnæs, K., and ArnbjergNielsen, K.: Framework for economic pluvial flood risk assessment considering climate change effects and adaptation benefits, J. Hydrol., 414-415, 539-549, https://doi.org/10.1016/j.jhydrol.2011.11.031, 2012. 